\title{
Line Managers' Performance of Strategic Human Resource Roles: Creating Value, Not Rhetoric
}

\author{
Rashed Mahmud Shakil, Mohamed Ayyub Bin Hassan, Beni Widarman Bin Yus Kelana, Md \\ Alamgir Mollah, Md Sohel Chowdhury
}

\begin{abstract}
Line managers' (LMs) role has been restructured in modern business as they are undertaking the responsibilities of key human resource management (HRM) functions. Although HRM roles of LMs have got wide recognition in academic research, factors influencing their performance of strategic HRM roles remained relatively under developed, especially in Bangladesh. Based on the perspective of Ability-Motivation-Opportunity (AMO) theory, we propose that LMs' strategic HR roles performance are influenced by their ability, motivation, and opportunity. A survey with self-administered questionnaire was applied for collecting data from a sample of 170 participants drawn from LMs employed at private banking organizations in Bangladesh. The technique of partial least squares structural equation modelling was utilized for testing the study model. The findings highlighted that LMs' ability and motivation significantly related to their performance of strategic HR roles while opportunity provided to LMs had non-significant relationship with their strategic HR roles. Despite the findings produced mixed support, this research has key implications for practitioners as well as academicians. The present research is believed to serve as a standard in comprehending the AMO factors influencing LMs' execution of strategic $H R$ roles which remains largely unexplored in the Bangladesh context.
\end{abstract}

Keywords: Ability, Change Agent, Motivation, Opportunity, Strategic Partner.

\section{INTRODUCTION}

Contemporary organizations are undergoing sustained pressure for improving the efficiency of human resource (HR) roles by reconsidering the strategies of managing employees effectively. This transformation in HR roles usually happen when HR functions are assigned to line managers (LMs) instead of HR professionals [1]. Even though the intended practices of human resource management (HRM) are designed well by HR professionals, they will lose effectiveness if they are not implemented properly by LMs. In the existing Strategic HRM literature, LMs play a key part in HRM implementation as they are considered as the primary

Revised Manuscript Received on October15, 2019

Rashed Mahmud Shakil*, School of Human Resources Development \& Psychology, Universiti Teknologi Malaysia, Johor Bahru, Malaysia. Email: rs.shaki11310@gmail.com

Mohamed Ayyub Bin Hassan, School of Human Resources Development \& Psychology, Universiti Teknologi Malaysia, Johor Bahru, Malaysia. Email: ayyub@utm.my

Beni Widarman Bin Yus Kelana, Azman Hashim International Business School, Universiti Teknologi Malaysia, Johor Bahru, Malaysia. Email: beni@utm.my

Md Alamgir Mollah, Graduate School of Business, Keimyung University, People's Republic of Korea. Email: alamgir1003@yahoo.com

Md Sohel Chowdhury, Department of Management Studies, University of Barishal, Bangladesh. Email: mschowdhury@bu.ac.bd enactor of HR policies at the business level [2]. Generally LMs execute the responsibility for multiple HR functions namely appraisal, pay compensation, training and development, on the-job coaching, and motivating teams [3].

However, LMs are found to have lack of ability to perform HR roles [4], not motivated to take on HRM issues [5], and get inadequate opportunity from HR professionals to execute HR functions effectively [6]. In short, LMs' lack of ability, motivation, and opportunity hinder the performance of their HR roles strategically. Additionally Ulrich [7] identified strategic partner and change agent as the two dimensions of strategic HR roles. Although LMs playing the strategic role of HR tend to increase the chance of ensuring HR effectiveness, past researchers shed less light on such roles compared to operational HR roles. This view was supported by the study of Ulrich [7] opining that strategic roles of HR is less established at the organizational level. In their study, Guzman et al. [8] reported the findings that the professionals of Asia mostly focus on performing traditional operational roles, placing less emphasis on performing strategic HR roles. This evident gap spurred the researchers to conduct the study based on LMs' strategic HR roles. Ability-Motivation-Opportunity (AMO) theory proposed by Appelbaum et al. [9] is widely applied in the research of HRM-performance. According to the AMO model, the performance of individuals rests with three variables namely abilities (A) of individuals, motivation (M), and opportunities $(\mathrm{O})$ for participation. Likewise, Gerhart [10] held his view that HRM practices tend to influence individual's ability (e.g., applying proper hiring, training, and selection requirements), motivation (e.g., applying performance-based pay), opportunity (e.g., applying team spirit or suggestion methods) for contributing to business performance. However, we applied AMO theory differently in this article: instead of emphasizing on how applied HRM practices influence employees' behaviour and attitudes [9], [11], [12], we predict that LMs' ability, motivation, and opportunity will influence their strategic HR performance. The selection of LMs' AMO predicting HR role performance was in line with the study of prior researchers [1], [13], [14]. Taking this stance into account, the AMO theory is operationalized in this study for explaining LMs' implementation of strategic HR roles.

In the previous literature it has been shown that LMs' ability, motivation, and opportunity factor predict their strategic HR roles performance, more specifically strategic partner and change agent role.

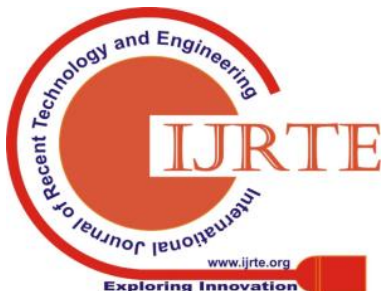




\section{Line Managers' Performance of Strategic Human Resource Roles: Creating Value, Not Rhetoric}

It is proposed in the classic work performance theory that AMO variables determine the performance of individuals [11]. The study of Waeyenberg and Decramer [15] argued that the performance management systems are implemented effectively when LMs possess AMO factors. Substantiating this view, numerous studies [1], [13], [14] attempted to demonstrate that LMs' implementation of HR roles strategically is influenced by their possession of ability, motivation and opportunity in performance. Based on the aforementioned view, this study is focused on LMs' AMO to perform strategic HR roles.

\section{A. Objective}

This study set the objective of examining the influence of LMs' ability, motivation, and opportunity on their performance of strategic HR roles such as strategic partner and change agent. To achieve that, the study will investigate the influence of: (a) ability on strategic partner; (b) ability on change agent; (c) motivation on strategic partner; (d) motivation on change agent; (e) opportunity on strategic partner; and (f) opportunity on change agent.

\section{METHODOLOGY}

\section{A. Sample}

The nature of the current research is cross-sectional where data were accumulated from LMs employed in private commercial banks in Bangladesh. In addition, the method of purposive judgemental sampling was applied in this study. The researchers distributed total 308 questionnaires and finally 195 questionnaires were received through the HR managers. After analysing 195 questionnaires, 25 were removed because of uncompleted answers. Then researchers considered 170 questionnaire in total for final data analysis that represented $55.2 \%$ of response rate. With the reference to Sekaran and Bougie [16], the acceptable response rate is $30 \%$ to perform the analysis of study.

\section{B. Measurement}

The factor of ability was operationalized as LMs' occupational capacities, experience, training, related courses, managing time for performance, and handling obstacles of HR related functions. The scale of ability was adapted from Bos-Nehles' [17] study using seven items. Moreover, the factor of motivation was operationalized as LMs' interest, willingness and commitment for performing HR functions and the measurement for motivation was also adapted from Bos-Nehles [17] applying eight items. Furthermore, the opportunity factor was operationalized as getting the support services and supportive behaviors from HR professionals and seven-items scale adapted from Bos-Nehles [17] was employed to measure the opportunity. Last but not the least, the scale of strategic HR roles in particular strategic partner and change agent was adapted from Ulrich [7], and both roles were measured using ten items each. All variables were assessed by applying five point Likert scale that ranged between 1 implying "strongly disagree" and 5 implying "strongly agree".

\section{Statistical Analysis}

The partial least squares (PLS) is popular because of its ability of handling multivariate analysis [18], coupled with causal modelling. The analytical procedure with two-steps in PLS-SEM incorporating measurement and structural model was applied for analysing data. Also, Statistical Package for Social Sciences (SPSS) - version 23 was also applied for conducting descriptive statistical analysis.

\section{RESULTS}

\section{A. Measurement Model}

Convergent validity was measured for supporting construct validity which denotes all indicators assess the construct which they are assumed to assess [18]. It was recommended by Hair et al. [19] that three calculations namely the factor loadings, composite reliability (CR), and average variance extracted (AVE) are compulsory for measuring convergent validity. Based on the recommendation of Hair et al. [19], the value of loadings must be 0.708 or above, and value of loadings between 0.4 and 0.708 is considered acceptable if the AVE score is greater than 0.50 and CR greater than 0.60 . In this study, two items (M6, M7) of motivation and one item (A1) of ability were deleted because of low loading value. Afterwards, the range of AVE value was found from 0.506 to 0.635 which were above .50 as per the recommendation of Hair et al. [19]. Moreover, the range of CR in this study was between 0.859 and 0.945 , fulfilling the threshold value of 0.70 proposed by Hair et al. [19]. The Table- I illustrates the detailed results of measurement model. Altogether, this study exhibited the convergent validity satisfactorily.

Table- I: Summary of measurement model results

\begin{tabular}{|c|c|c|c|c|}
\hline Construct & $\begin{array}{c}\text { Measurement } \\
\text { Items }\end{array}$ & Loading & $\begin{array}{l}\text { Average } \\
\text { Variance } \\
\text { Extracted }\end{array}$ & $\begin{array}{l}\text { Composite } \\
\text { Reliability }\end{array}$ \\
\hline \multirow[t]{6}{*}{ Motivation } & M1 & 0.857 & \multirow[t]{6}{*}{0.525} & \multirow[t]{6}{*}{0.865} \\
\hline & M2 & 0.791 & & \\
\hline & M3 & 0.776 & & \\
\hline & M4 & 0.698 & & \\
\hline & M5 & 0.703 & & \\
\hline & M8 & 0.451 & & \\
\hline \multirow[t]{6}{*}{ Ability } & $\mathrm{A} 2$ & 0.691 & \multirow[t]{6}{*}{0.506} & \multirow[t]{6}{*}{0.859} \\
\hline & A3 & 0.768 & & \\
\hline & A4 & 0.793 & & \\
\hline & A5 & 0.669 & & \\
\hline & A6 & 0.662 & & \\
\hline & A7 & 0.671 & & \\
\hline \multirow[t]{5}{*}{ Opportunity } & O1 & 0.813 & \multirow[t]{5}{*}{0.580} & \multirow[t]{5}{*}{0.906} \\
\hline & $\mathrm{O} 2$ & 0.832 & & \\
\hline & $\mathrm{O} 3$ & 0.715 & & \\
\hline & O4 & 0.810 & & \\
\hline & O5 & 0.664 & & \\
\hline
\end{tabular}




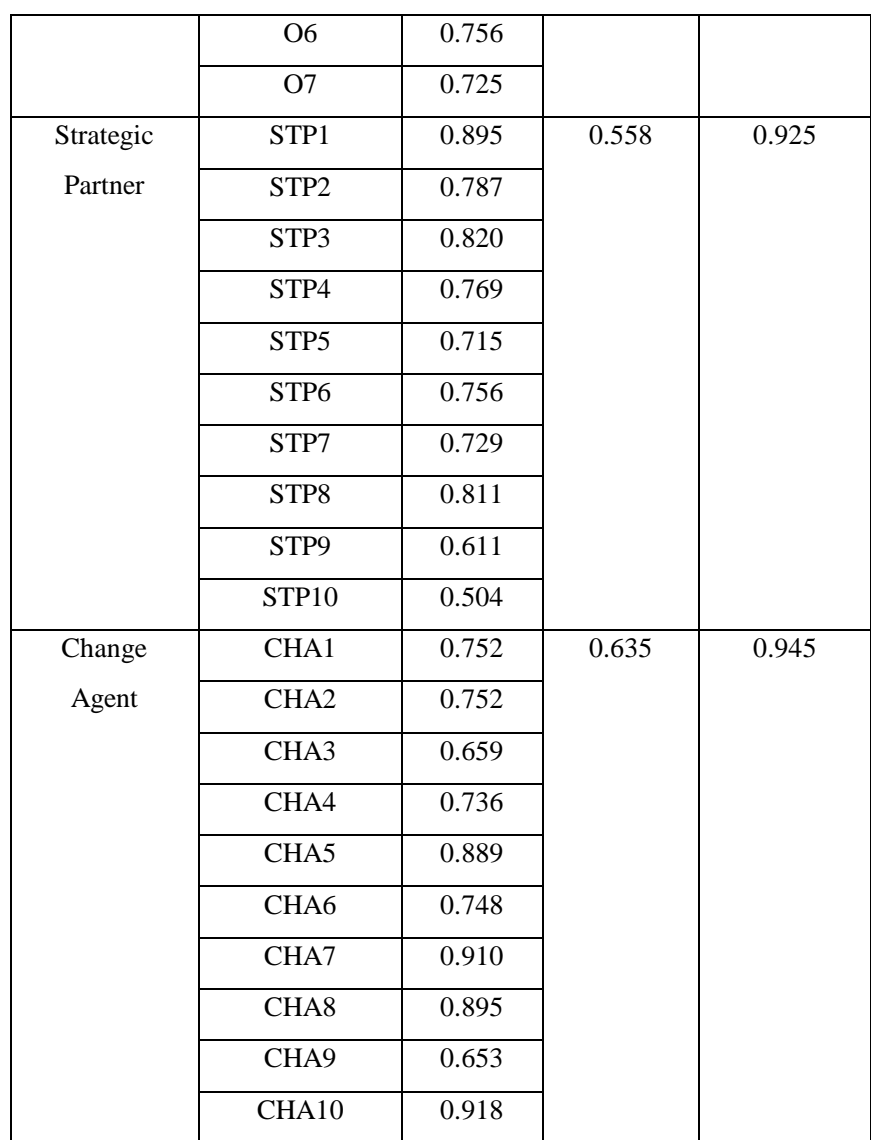

Source: Output from the results of the analysis.

Subsequently, discriminant validity portrays the degree to which conceptually similar two constructs are dissimilar [18]. Discriminant validity might be measured based on three criteria (cross loading, HTMT criterion, Fornell-Larcker criterion) [20]. In cross loading, the loadings of all indicators of an assigned construct must be greater than the loadings of other constructs [20]. This study found all loadings of indicators exceeding the threshold value of 0.6, as suggested by Hair et al. [18]. Next, Fornell and Larcker [21] criterion indicates that square-root of AVE of all latent constructs at the diagonal level should be greater than other off-diagonal values of correlation which is evident in Table- II. Additionally, based on the proposition of Henseler et al. [22], the problem of discriminant validity arises when the HTMT value is greater than 0.90 for HTMT.90. As displayed in TableIII, all values are below 0.90. Therefore, this study fulfilled all criteria in order to get satisfactory discriminant validity.

Table- II: Discriminant Validity (Fornell-Larcker criterion)

\begin{tabular}{|l|l|l|l|l|l|}
\hline & 1 & 2 & 3 & 4 & 5 \\
\hline 1. Ability & $\mathbf{0 . 7 1 0}$ & & & & \\
\hline 2. Change Agent & 0.377 & $\mathbf{0 . 7 9 5}$ & & & \\
\hline 3. Motivation & 0.308 & 0.438 & $\mathbf{0 . 7 2 4}$ & & \\
\hline 4. Opportunity & 0.285 & 0.135 & 0.157 & $\mathbf{0 . 7 5 9}$ & \\
\hline 5. Strategic Partner & 0.428 & 0.666 & 0.464 & 0.229 & $\mathbf{0 . 7 4 7}$ \\
\hline
\end{tabular}

Source: Output of the analysis

Note: The squared root of AVE is represented in the diagonal, while other entries indicate the correlations.
Table- III: Discriminant Validity (HTMT criterion)

\begin{tabular}{|l|l|l|l|l|l|}
\hline & 1 & 2 & 3 & 4 & 5 \\
\hline 1. Ability & & & & & \\
\hline $\begin{array}{l}\text { 2. Change } \\
\text { Agent }\end{array}$ & 0.402 & & & & \\
\hline 3. Motivation & 0.329 & 0.377 & & & \\
\hline $\begin{array}{l}\text { 4. Opportunity } \\
0.317\end{array}$ & 0.141 & 0.178 & & \\
\hline $\begin{array}{l}\text { 5. Strategic } \\
\text { Partner }\end{array}$ & 0.439 & 0.717 & 0.430 & 0.225 & \\
\hline
\end{tabular}

Source: Output of the analysis

\section{B. Structural Model}

Once the goodness of measure is achieved, the assessment of structural model need to be followed. Initially, this research investigated $\mathrm{R}^{2}$ indicating the model's predictive accuracy. $\mathrm{R}^{2}$ could be considered as the extent of variance that all exogenous constructs explain in the endogenous constructs [20]. The rule of thumb regarding the acceptability of $R^{2}$ was provided by Cohen [23] referring that $\mathrm{R}^{2}$ value greater than 0.25 indicate substantial, 0.13 to 0.24 indicate moderate, and 0.02 to 0.12 indicate weak level. This study found $R^{2}$ values pertaining to all endogenous constructs namely strategic partner and change agent of 0.313 and 0.256 respectively indicating substantial predictive accuracy level. According to the Table- IV, four out of six hypotheses were supported since p-value is below .01 and t-value is above 1.96. The findings of the structural model are explained in the following:

- Ability of LMs was significantly related to their strategic partner role $(\beta=0.291, p<.01)$.

- Ability of LMs was significantly related to their change agent role $(\beta=0.267, p<.01)$.

- Motivation of LMs was significantly related to their strategic partner role $(\beta=0.361, p<.01)$.

- Motivation of LMs was significantly related to their change agent role $(\beta=0.355, p<.01)$.

- Opportunity provided to LMs was not significantly related to their strategic partner role $(\beta=0.090, p>.05)$.

- Opportunity provided to LMs was not significantly related to their change agent role $(\beta=0.003, p>.05)$.

Table- IV: Structural model results

\begin{tabular}{|c|c|c|c|c|}
\hline Path & $\begin{array}{c}\text { Standard } \\
\text { Beta }\end{array}$ & $\begin{array}{c}\text { Standard } \\
\text { Error }\end{array}$ & $\boldsymbol{t}$-value & Decision \\
\hline $\begin{array}{c}\text { Ability } \rightarrow \\
\text { Change Agent }\end{array}$ & 0.267 & 0.072 & $3.703^{* *}$ & Supported \\
\hline $\begin{array}{c}\text { Ability } \rightarrow \\
\text { Strategic Partner }\end{array}$ & 0.291 & 0.068 & $4.286^{* *}$ & Supported \\
\hline $\begin{array}{c}\text { Motivation } \rightarrow \\
\text { Change Agent }\end{array}$ & 0.355 & 0.063 & $5.645^{* *}$ & Supported \\
\hline $\begin{array}{c}\text { Motivation } \rightarrow \\
\text { Strategic Partner }\end{array}$ & 0.361 & 0.055 & $6.585^{* *}$ & Supported \\
\hline $\begin{array}{c}\text { Opportunity } \rightarrow \\
\text { Change Agent }\end{array}$ & 0.003 & 0.078 & 0.039 & Rejected \\
\hline $\begin{array}{c}\text { Opportunity } \rightarrow \\
\text { Strategic Partner }\end{array}$ & 0.090 & 0.070 & 1.280 & Rejected \\
\hline Source: Output
\end{tabular}

Source: Output of the analysis

Notes: $* * p<0.01, * p<0.05$. 


\section{Line Managers' Performance of Strategic Human Resource Roles: Creating Value, Not Rhetoric}

\section{DISCUSSION}

In this research, we analysed the association amongst ability, motivation, and opportunity of LMs and their performance of strategic HR roles in the private banking organizations. There was strong support of present study results proposing that ability factor has significant and positive influence on performing change agent and strategic partner role. Bos-Nehles et al. [14] lent their support with this study's results arguing that LMs' ability had direct positive influence on implementing HR strategically. Additionally, the capability of LMs' in performing HR roles in strategic manner accelerate their implementation of HR practices [24].

The findings placed emphasis on the significance of enhancing motivation of LMs because such motivation is directly related to their performance of strategic partner and change agent role in the work-setting. The results of this study were substantiated by the results of Bos-Nehles and Meijerink [2], reporting that the motivation of LMs had strong and positive influence on their HR role implementation. Other scholars like Guest and Bos-Nehles [5] maintained that when LMs are motivated and enthusiastic, they get themselves involved in performing strategic HR responsibilities.

It was also shown in this study findings that opportunity provided to LMs by HR professionals had no significant relationship with their change agent and strategic partner role performance. This view was in agreement with the empirical investigation of Mat et al. [25], concluding that LMs get slow feedback and inconsistent support from their HR counterparts which hinder their effective performance of HR roles. Despite HR-line partnership is recognized in the current Strategic HRM literature, this situation is not occurring widely to all organizations [6]. The consensus was made by McGuire et al. [26] and McConville [27] contending that lack of support as well as sense of distance exists between LMs and HR professionals, thereby leading them to perform poor HR role performance.

\section{CONCLUSION}

Despite line managers' (LMs) critical role in implementing HRM are acknowledged in the burgeoning literature, the theoretical and empirical investigation of how AMO theory is linked with HR role performance have remained under-researched until recently. By doing so, our research made contribution to the theory and research of strategic HRM by examining the assertion of Becker and Huselid [28] in the way that performing HR roles strategically plays critical role in enacting HR, thereby resulting the achievement of organizational outcomes. Moreover, we formulated and tested a model highlighting three factors based on A-M-O model like ability (A), motivation (M), and opportunity (O) and how these factors predict LMs' performance of strategic partner and change agent role. Examining this model will make crucial contribution to the extant literature by augmenting knowledge of less-studied relationship between HR implementation and individual outcomes.

\section{REFERENCES}

1. H. Bainbridge, "Devolving people management to the line: How different rationales for devolution influence people management effectiveness," Pers. Rev., vol. 44, no. 6, pp. 847-865, 2015.

2. A. C. Bos-Nehles and J. G. Meijerink, "HRM implementation by multiple HRM actors: a social exchange perspective," Int. J. Hum. Resour. Manag., vol. 29, no. 22, pp. 3068-3092, 2018.

3. I. Hunter, J. Saunders, and S. Constance, HR Business Partners. Hampshire: Routledge, Taylor \& Francis Group, 2016.

4. S. Hutchinson and J. Purcell, "Managing ward managers for roles in HRM in the NHS: overworked and under-resourced," Hum. Resour. Manag. J., vol. 20, no. 4, pp. 357-374, 2010.

5. D. Guest and A. C. Bos-Nehles, "HRM and performance: The role of effective implementation," in HRM and performance: Achievements and challenges, D. E. Guest, J. Paauwe, and P. Wright, Eds Chichester: Wiley Blackwell, 2013, pp. 79-96.

6. S. Op de Beeck, J. Wynen, and A. Hondeghem, "HRM implementation by line managers: explaining the discrepancy in HR-line perceptions of HR devolution," Int. J. Hum. Resour. Manag., vol. 27, no. 17, pp. 1901-1919, 2016.

7. D. Ulrich, "Human resource champions: The new agenda for adding value and delivering results," Acad. Manag. Rev., vol. 23, no. 1, pp. 178-180, 1997.

8. D. G. M. Guzman, J. P. Neelankavil, and K. Sengupta, "Human resources roles: ideal versus practiced: a cross-country comparison among organizations in Asia," Int. J. Hum. Resour. Manag., vol. 22 no. 13, pp. 2665-2682, 2011.

9. E. Appelbaum, T. Bailey, P. B. Berg, A. L. Kalleberg, and T. A. Bailey, Manufacturing advantage: Why high-performance work systems pay off. Ithaca, NY: Cornell University Press, 2000.

10. B. Gerhart, "Human resources and business performance: Findings, unanswered questions, and an alternative approach," Manag. Rev., vol. 16, no. 2, pp. 174-185, 2005.

11. I. Beltrán-Martín and J. C. Bou-Llusar, "Examining the intermediate role of employee abilities, motivation and opportunities to participate in the relationship between HR bundles and employee performance," BRQ Bus. Res. Q., vol. 21, no. 2, pp. 99-110, 2018.

12. K. Jiang, R. Takeuchi, and D. Lepak, P, "Where do We Go From Here? New Perspectives on the Black Box in Strategic Human Resource Management Research," J. Manag. Stud., vol. 50, no. 8, pp. 1448-1480, Aug. 2013.

13. C. Gilbert, D. S. Winne, and L. Sels, "Strong HRM processes and line managers' effective HRM implementation: a balanced view," Hum Resour. Manag. J., vol. 25, no. 4, pp. 600-616, 2015.

14. A. C. Bos-Nehles, V. M. J. Riemsdijk, and K. J. Looise, "Employee perceptions of line management performance: applying the AMO theory to explain the effectiveness of line managers' HRM implementation," Hum. Resour. Manage., vol. 52, no. 6, pp. 861-877, 2013.

15. T. Van Waeyenberg and A. Decramer, "Line managers' AMO to manage employees' performance: the route to effective and satisfying performance management," Int. J. Hum. Resour. Manag., vol. 29, no 22, pp. 3093-3114, 2018.

16. U. Sekaran and R. Bougie, Research methods for business: A skill building approach (7th edition). London: John Wiley \& Sons Inc., 2016.

17. A. Bos-Nehles, "The line makes the difference: line managers as effective HRM partners," PhD Thesis, Universiteit Twente, Enschede, Netherlands., 2010.

18. J. F. J. Hair, J. W. Black, B. J. Babin, and E. R. Anderson, Multivariate data analysis (7th edition). Upper Saddle River, New Jersey: Pearson Education Limited, 2010.

19. J. F. J. Hair, G. T. M. Hult, C. Ringle, and M. Sarstedt, A primer on partial least squares structural equation modeling (PLS-SEM) (2nd edition). Thousand Oaks, CA: Sage Publications Inc., 2017.

20. T. Ramayah, J. Cheah, F. Chuah, H. Ting, and M. A. Memon, Partial least squares structural equation modeling (PLS-SEM) using SmartPLS 3.0: An updated and practical guide to statistical analysis, 2nd ed. Singapore: Pearson Education Limited, 2018. 
21. C. Fornell and D. F. Larcker, "Evaluating structural equation models with unobservable variables and measurement error," J. Mark. Res., vol. 18 , no. 3 , pp. 39-50, 1981.

22. J. Henseler, C. M. Ringle, and M. Sarstedt, "A new criterion for assessing discriminant validity in variance-based structural equation modeling," J. Acad. Mark. Sci., vol. 43, no. 1, pp. 115-135, 2015.

23. J. Cohen, Statistical power analysis for the behavioral sciences (2nd revised edition). New York, NY: Routledge, Taylor \& Francis Group, 2013.

24. F. T. Azmi and S. Mushtaq, "Role of line managers in human resource management: empirical evidence from India," Int. J. Hum. Resour. Manag., vol. 26, no. 5, pp. 616-639, 2015.

25. N. H. N. Mat, H. S. Salleh, W. N. Mohamed, and Y. Yusof, "Enacting the HRM Role: What Matters to Line Managers?," Mediterr. J. Soc. Sci., vol. 6, no. 3, pp. 535-543, 2015.

26. F. McGuire, D. McGuire, and M. Sanderson, "Between A rock and a hard place: An exploration of line manager partnership working with trade unions and the HR function. University Forum for Human Resource Development," in http://www. ufhrd. co $u k /$ wordpress/mcguire-f-mcguire-d-and-sanderson-m-between-a-rock and-a-hard-place-an-exploration-of-line-manager-partnership-worki ng-with-trade-unionsand-the-hr-function, 2011.

27. T. McConville, "Devolved HRM responsibilities, middle-managers and role dissonance," Pers. Rev., vol. 35, no. 6, pp. 637-653, 2006.

28. B. E. Becker and M. A. Huselid, "Strategic human resources management: where do we go from here?," J. Manage., vol. 32, no. 6, pp. 898-925, 2006.

\section{AUTHORS' PROFILE}

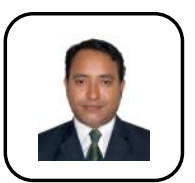

Rashed Mahmud Shakil is a lecturer in BGC Trust University Bangladesh. He received Bachelor of Business Administration and Master of Business Administration from University of Dhaka, Bangladesh. He also received Master of Philosophy (Human Resources Development) from Universiti Teknologi Malaysia, Malaysia. His research area includes Human Resources Management, Leadership and Organizational Behaviour (rs.shakil1310@gmail.com)

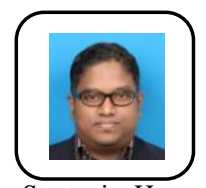

Mohamed Ayyub Bin Hassan is a senior lecture of Universiti Teknologi Malaysia (UTM). He had Master in Human Resources Development and PhD from UTM. His research area includes Human Resources Development, Strategic Human Resources Management, and Organizational Behaviour (ayyub@utm.my)

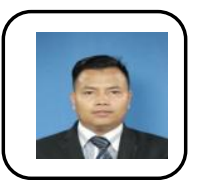

Beni Widarman Bin Yus Kelana is a senior lecture of Universiti Teknologi Malaysia (UTM). He had Master in Management and $\mathrm{PhD}$ from UTM. His research area includes Human Resources Development, Human Resources Sustainability, Organizational Behavior, Continuous Professional Development, Small Medium Enterprise (SMEs) (beni@utm.my)

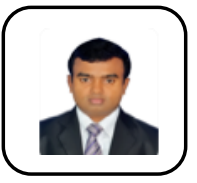

Md. Alamgir Mollah is an assistant professor in University of Barisal, Bangladesh. He received Bachelor of Business Administration and Master of Business Administration (MBA) from University of Dhaka, Bangladesh. He also received another MBA from South China University of Technology, Guangzhou, China. He has started PhD (HRM and Organizational Behavior) in Keimyung University, Republic of Korea in 2019. His research area includes Human Resources Management, Innovation and Technological Management, and Strategic Management (alamgir1003@yahoo.com)

Md Sohel Chowdhury is an assistant professor in University of Barisal, Bangladesh. He received Bachelor of Business Administration and Master of Busines
Administration from University of Dhaka, Bangladesh. Currently he is pursuing $\mathrm{PhD}$ majoring in Organizational Behavior and Human Resource Management in Inha University, Republic of Korea. His research area includes e-Recruitment, job design and strategic HRM (mschowdhury@bu.ac.bd)

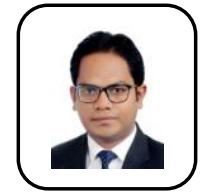

